\title{
Factors Influencing Gelation and Rennetability of Camel Milk using Camel Chymosin
}

Hailu, Yonas; Ipsen, Richard; Hansen, Egon Bech; Seifu, Eyassu; Eshetu, Mitiku

Publication date:

2015

Document Version

Publisher's PDF, also known as Version of record

Link back to DTU Orbit

Citation (APA):

Hailu, Y., Ipsen, R., Hansen, E. B., Seifu, E., \& Eshetu, M. (2015). Factors Influencing Gelation and Rennetability of Camel Milk using Camel Chymosin. Poster session presented at 9th NIZO Dairy Conference, Papendal, Netherlands.

\section{General rights}

Copyright and moral rights for the publications made accessible in the public portal are retained by the authors and/or other copyright owners and it is a condition of accessing publications that users recognise and abide by the legal requirements associated with these rights.

- Users may download and print one copy of any publication from the public portal for the purpose of private study or research.

- You may not further distribute the material or use it for any profit-making activity or commercial gain

- You may freely distribute the URL identifying the publication in the public portal

If you believe that this document breaches copyright please contact us providing details, and we will remove access to the work immediately and investigate your claim. 


\title{
Factors Influencing Gelation and Rennetability of Camel Milk using Camel Chymosin
}

\author{
Yonas Hailu ${ }^{\sharp}$, Richard Ipsen ${ }^{*}$, Egon Bech Hansen ${ }^{\$}$, Eyassu Seifu ${ }^{\S}$ and Mitiku Eshetu ${ }^{\square}$.
}

${ }^{\square}$ Haramaya University, Ethiopia, ${ }^{\sharp}$ University of Copenhagen, ${ }^{\S}$ Technical University of Denmark, ${ }^{\S}$ Botswana College of Agriculture, Botswana

\section{ABSTRACT}

Effect of temperature $(\mathrm{T}), \mathrm{pH}$ and chymosin $\left(\mathrm{CHY}-\mathrm{MAX}{ }^{\circledR} \mathrm{M}\right)$ concentration (CC) on caseinomacropeptide (CMP) release and gelation of camel milk was studied. Results revealed significant $(\mathrm{p}<0.05)$ effects of $\mathrm{T}, \mathrm{pH}$ and $\mathrm{CC}$ on the rate of $\kappa$-casein $(\kappa-\mathrm{CN})$ hydrolysis and the interaction between $\mathrm{T}$ and $C C$ significantly $(p<0.05)$ affected gel development. A high level of CC (85 IMCU $\mathrm{L}^{-1}$ ) and $\mathrm{T}\left(40^{\circ} \mathrm{C}\right.$ ) was needed to obtain satisfactory gelation parameters and in all cases $>95 \%$ CMP was found to be released from the casein $(\mathrm{CN})$ micelle prior to aggregation.

\section{INTRODUCTION}

The composition of camel milk protein differs from milk of other species and $\mathrm{CN}$ micelles from camel milk have a larger average diameter ( 380 $\mathrm{nm}$ ) than bovine $\mathrm{CN}$ micelles ${ }^{1}$. The distribution of the different $\mathrm{CNs}$ is also substantially different, mainly in that camel milk has a smaller proportion of $\kappa-\mathrm{CN}(3.5 \%$ of the total $\mathrm{CN})$ and relatively much more $\beta-\mathrm{CN}(65 \%$ of total $\mathrm{CN})^{2}$ than bovine milk, where the proportions are $12 \%$ and $33 \%$, respectively ${ }^{3}$. Until recently a suitable coagulant enzyme (i.e. camel chymosin) was not obtainable, hence very limited studies are available on $\kappa-\mathrm{CN}$ hydrolysis and gelation of camel milk.

\section{METHODOLOGY}

The release of CMP was determined by size exclusion HPLC $^{4}$. Rennetability and gelation of camel milk were followed using a free oscillating rheometer (ReoRox G2, Medirox, Nyköping, Sweden). Rate constant $(\mathrm{K})$ for $\kappa-\mathrm{CN}$ hydrolysis was determined by fitting in to a first order kinetics model (i.e. $\boldsymbol{C M P}=\boldsymbol{C} \boldsymbol{M} \boldsymbol{P}_{\infty}\left(\mathbf{1}-\boldsymbol{e}^{-\boldsymbol{K} \mathrm{t}}\right)$. Gelation time $\left(\mathrm{t}_{\mathrm{g}}\right)$, time interval from $t_{g}$ until $G^{\prime}$ reached a value $\left(\frac{G_{\infty}^{\prime}}{e}\right)(\boldsymbol{\tau}), G^{\prime}$ value at $t=\infty$ $\left(G_{\infty}^{\prime}\right)$ were predicted using Scott Blair equation (i.e. $\mathbf{G}^{\prime}=\mathbf{G}_{\infty} * \boldsymbol{e}^{\left(-\tau /\left(\mathbf{t}-\mathbf{t}_{\mathbf{g}}\right)\right)}$. Where $(t)$ is time after chymosin addition and $\left(G^{\prime}\right)$ is storage modulus.

\section{RESULTS}

Gelation of caseins started after $>95 \%$ CMP released from casein micelle. Variation in lag phase of gel development was observed for different levels of $\mathrm{T}$ (Fig. 1).

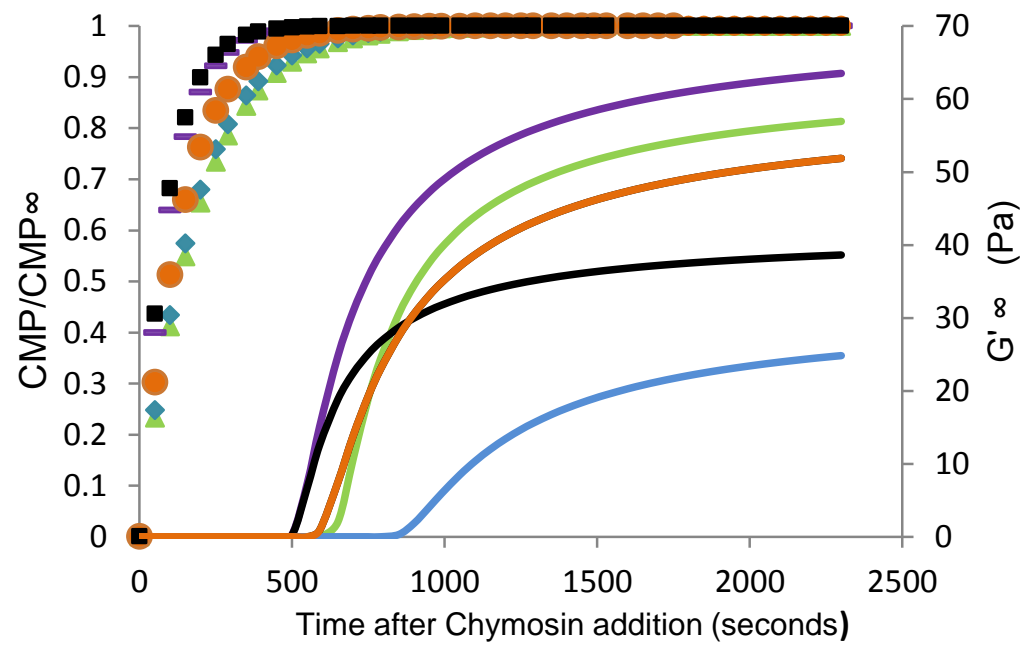

Fig 1. Effect of $\mathrm{T}, \mathrm{CC}$ and $\mathrm{pH}$ on camel $\mathrm{\kappa}-\mathrm{CN}$ hydrolysis and gelation (solid lines). $\mathrm{T}(\diamond) 30^{\circ} \mathrm{C}$ and $\left((\bullet) 40^{\circ} \mathrm{C}, 55 \mathrm{IMCU} \mathrm{L}^{-1}\right)$ and $\mathrm{CC}(\bullet) 85 \mathrm{IMCU}$ $\mathrm{L}^{-1} ; \mathrm{pH}(\Delta) 6.6$ and $(-) 6.0$.
The $\kappa-\mathrm{CN}$ hydrolysis rate has a negative correlation of 0.693 with $t_{g}$

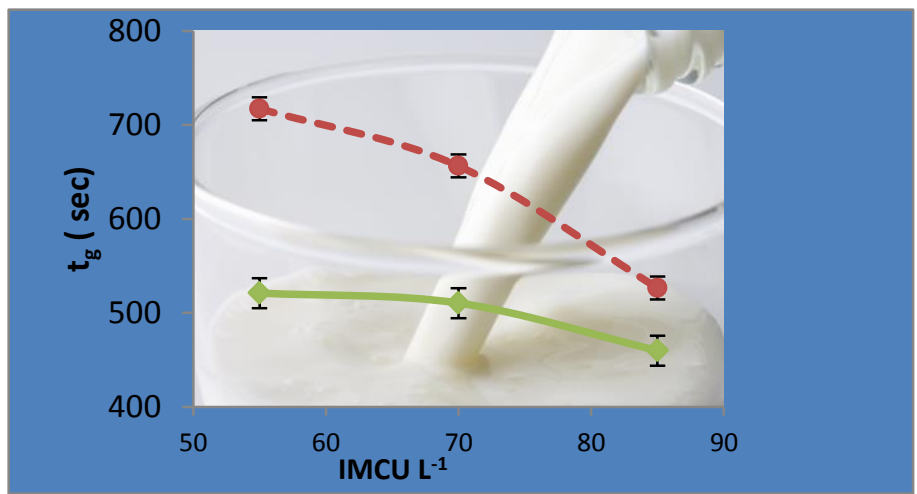

Fig 2. Gelation time $\left(\mathrm{t}_{\mathrm{g}}\right)$ of camel milk as a function of $\mathrm{T}$ and CC. $\ldots\left(30^{\circ} \mathrm{C}\right) \&-\left(40^{\circ} \mathrm{C}\right)$.

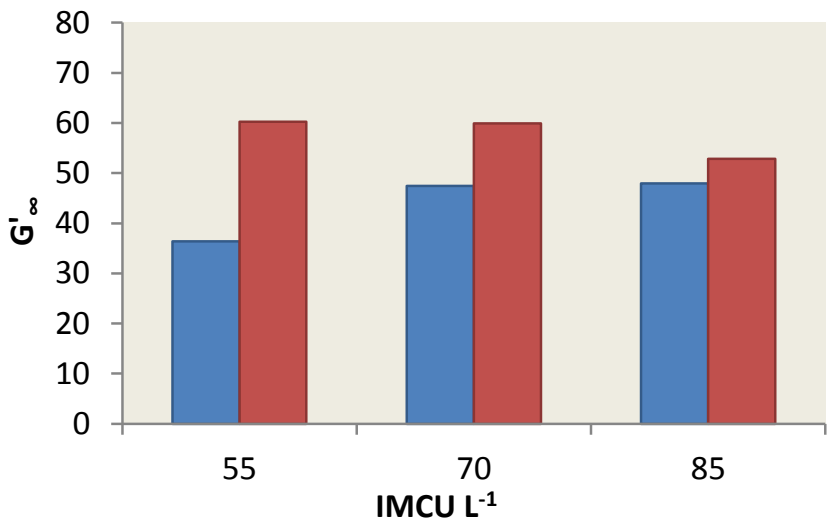

Fig 3. Storage module development at different $\mathrm{T}$ and $\mathrm{CC}$. $-30{ }^{\circ} \mathrm{C} \&=40^{\circ} \mathrm{C}$

\section{CONCLUSION}

More than $95 \%$ of the CMP has to be released from the $\kappa-C N$ of camel milk for the aggregation and gel formation to commence. The time of gelation was shown to be mainly affected by temperature ( $t_{g}$ shorter at 40 than $30{ }^{\circ} \mathrm{C}$ ) and by using a higher CC (85 IMCU L $\left.\mathrm{L}^{-1}\right)$ a comparable $\mathrm{G}_{\infty}^{\prime}$ was obtained irrespective of temperature.

\section{REFERENCES}

1. Bornaz et al. (2009). IJDT. 62(4):505-513.

2. Kappeler, S. (1998). PhD Thesis, ETH Zürich

3. Walstra, P. et al. (2006). Dairy Science and Technology

4. Van Hooydonk A.C.M., and Olieman C. (1982). NMDJ. 36.

Acknowledgments; Wholehearted gratefulness to Prof. Karsten Bruun Qvist for his dedicated guidance and encouragement. DANIDA is sincerely acknowledged for financial support. 